\title{
Consequences of yellow band disease (YBD) on Montastraea annularis (species complex) populations on remote reefs off Mona Island, Puerto Rico
}

\author{
Andrew W. Bruckner*, Robin J. Bruckner \\ NOAA Fisheries, Office of Habitat Conservation, Coral Reef Conservation Program, 1315 East West Highway, Silver Spring, \\ Maryland 20910, USA
}

\begin{abstract}
The rate and extent of mortality from yellow band disease (YBD) to Montastraea annularis (species complex) on reefs off Mona Island, Puerto Rico, was evaluated over 8 yr. Isolated YBD infections were first observed in 1996. Prevalence of YBD increased dramatically in 1999, with a maximum of $52 \%$ of all $M$. annularis colonies infected in 1 shallow site. YBD continued to spread among adjacent, previously uninfected corals over the next $4 \mathrm{yr}$, and disease prevalence progressively increased in deeper sites. Linear rates of disease advance and tissue mortality have been slow ( 5 to $15 \mathrm{~cm} \mathrm{yr}^{-1}$ ), although colonies with single YBD lesions have become infected in multiple locations. Most (85\%) colonies identified with YBD in 1999 and 2000 were still affected in 2003, and these corals have lost a mean of $60 \%$ of their living tissue. Mortality from YBD is being compounded by black band disease, white plague and other syndromes; bioeroding sponges, macroalgae, cyanobacteria and other competitors have colonized tissue-denuded skeleton, minimizing the likelihood of resheeting. The deteriorating health of $M$. annularis is of particular concern, as these are the dominant corals on these reefs, the largest ( 2 to $3 \mathrm{~m}$ diameter and height) and presumably oldest colonies were infected with YBD more frequently than small colonies, and no recruitment has been observed. YBD is causing extensive mortality to key reef-building taxa in a remote location where anthropogenic stressors are minimal. Additional research on causes of YBD, mechanisms of infection, and strategies to mitigate YBD is needed; otherwise, M. annularis may suffer a fate similar to that of the Atlantic acroporids.
\end{abstract}

KEY WORDS: Coral disease $\cdot$ Yellow band disease $\cdot$ YBD $\cdot$ Montastraea annularis

\section{INTRODUCTION}

Since the mid-1990s, scientists have documented an increase in the number of coral diseases, coral species affected, geographic extent, prevalence and incidence, and rates of associated coral mortality (Bruckner \& Bruckner 1997a, Santavy \& Peters 1997, Hayes \& Goreau 1998, Richardson et al. 1998, Sutherland et al. 2004, Weil 2004). Several studies have implicated human activities in the spread and increased prevalence and virulence of diseases (Harvell et al. 1999, Green \& Bruckner 2000). However, synergistic and cumulative effects of anthropogenic stressors have not been fully characterized, and few studies have evalu- ated whether remote locations are being impacted to the same degree as reefs near human population centers (Bruckner 2002, Woodley et al. 2003). In addition, most coral disease studies represent single or annual surveys and few have followed the fates of individual corals over time, making it difficult to determine the effects of disease on species composition and population dynamics of key reef-building corals (Green \& Bruckner 2000, Bruckner 2002).

Outbreaks of coral diseases have been reported over the last $10 \mathrm{yr}$ from a number of reefs off mainland Puerto Rico (Bruckner \& Bruckner 1997a, Bruckner 1999, Weil et al. 2002). Many of these reefs are located adjacent to developed shorelines and are affected by 
land-based sources of pollution and sediment. The primary objective of this study was to determine if reefs in remote locations were being affected by coral diseases to the same degree as nearshore sites. New information is presented on patterns of spread and extent of mortality from a yellow band disease (YBD) outbreak on reefs around Mona Island, $65 \mathrm{~km}$ off the west coast of Puerto Rico. YBD primarily affects slow-growing massive corals in the genus Montastraea, which are the dominant corals found on fore reef communities off Mona Island. Previous surveys around Mona Island have reported either an absence of disease or a low prevalence (Williams \& Bunkley Williams 1990, Goenaga \& Boulon 1991).

\section{MATERIALS AND METHODS}

In 1995 paired radial sites $(n=10)$, each $314 \mathrm{~m}^{2}$ in area, were randomly selected on 5 reefs (Carmelitas North, Carmelitas South, Mujeres West, Mujeres East and Carbinero; Fig. 1) off the west and south coasts of Mona Island to characterize the prevalence and impact of coral diseases. The center of each site was selected by dropping a small fishing weight from the surface of the boat, and was permanently marked with a stainless steel rebar. All corals within each site were counted, recorded to species, and assessed for the presence of disease in 1995 and 1996. In 1999, sites were reassessed using a modified Atlantic and Gulf Rapid Reef Assessment (AGRRA) protocol. Data were collected on the (1) species and maximum diameter and height of each coral $10 \mathrm{~cm}$ or larger, using a $1 \mathrm{~m}$ bar marked in $1 \mathrm{~cm}$ increments; (2) percent of recent and old mortality based on visual estimates from a planar view; and (3) causes of recent mortality, recorded as a particular disease, invertebrate or fish predation, algal competition and/or overgrowth by encrusting invertebrates. All survey data presented here were collected by A.W.B. to minimize observer variability.

In 1999 and 2000, up to 25 colonies of Montastraea faveolata, $M$ annularis and $M$. franksi on each reef were marked with numbered tags ( $\mathrm{n}=87$ corals), and 1 to 5 nails were placed in the exposed skeleton immediately behind the YBD to measure rates of tissue loss. Each site was reexamined in May and August of 2000, 2001 and 2003 to determine the prevalence of new infections and to measure rates and extent of tissue loss in tagged colonies. During each survey, all tagged colonies were photographed, and additional nails were placed in the skeleton immediately behind the YBD front to mark its position during that survey. The linear rate of advance was determined by measuring the distance the band had radiated out from the nails inserted in the skeleton during the previous survey. Estimates of the loss were made from a planar view by measuring the dimensions of exposed skeleton (maximum width and length) and the circumference of the band, and converting this to area $\left(\mathrm{cm}^{2}\right)$.

\section{RESULTS}

There were 2166 live colonies greater than $10 \mathrm{~cm}$ in diameter represented by 26 species of scleractinian corals within permanent sites at the beginning of the study. Colonies of Montastraea annularis, M. faveolata and $M$. franksi were the most abundant species, making up about $40 \%$ of all scleractinian corals. Most corals were between 25 and $70 \mathrm{~cm}$ in diameter. Colonies of $M$. annularis (species complex: mean diameter $=89 \mathrm{~cm}$, maximum $=480 \mathrm{~cm}$ ) were significantly larger $(t$-test, $\mathrm{p}<0.001)$ than other species $($ mean $=$ 38 cm; Fig. 2).
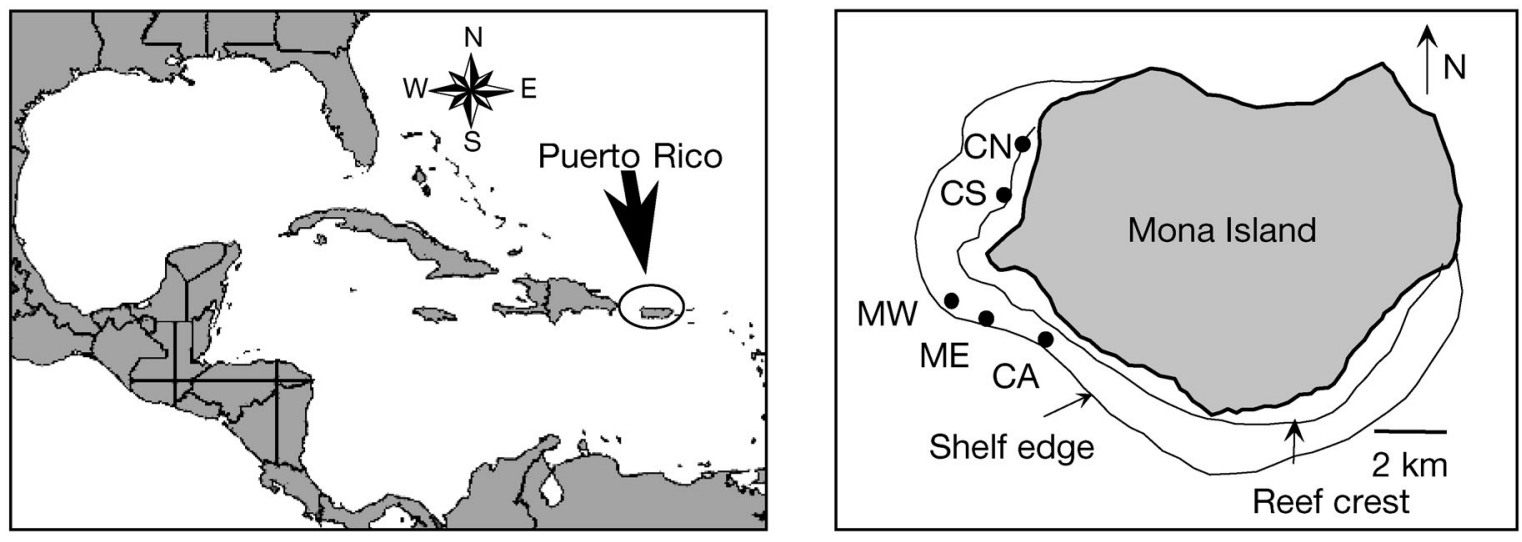

Fig. 1. Study sites on reefs of Mona Island, Puerto Rico. Carmelitas North (CN) and Carmelitas South (CS) were 4-10 m deep, Mujeres West (MW) and Mujeres East (ME) were 15-18 m deep, and Carbinero (CA) was 18-22 m deep 


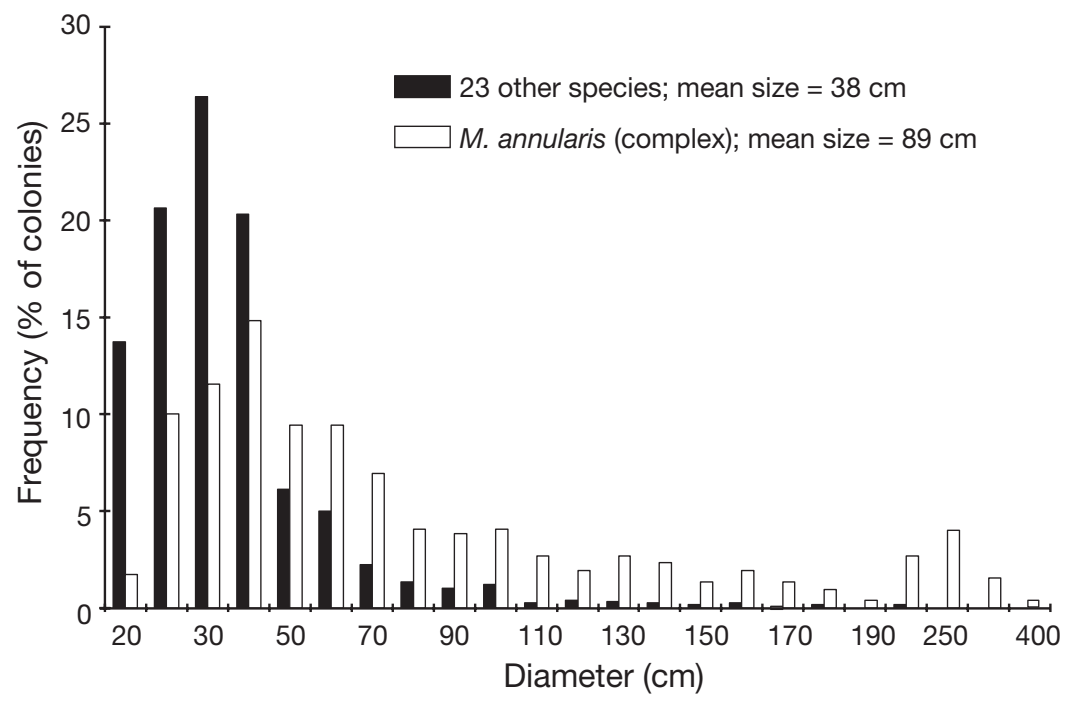

Fig. 2. Size frequency distribution of scleractinian corals within permanent study sites. White bars refer to the maximum diameter of colonies of Montastraea annularis complex; black bars are all other species pooled

New YBD infections had a focal distribution. Lesions were located peripherally or basally at the colony margin, or centrally within the colony surface forming a small circular blotch (1 to $5 \mathrm{~cm}$ diameter) that was surrounded by apparently healthy, fully pigmented tissue. Blotches progressively increased in diameter from a few $\mathrm{cm}$ up to $15 \mathrm{~cm}$. The tissue first affected (at center of the blotch) became darker yellow/brown and eventually died, with remaining affected tissue forming a characteristic crescent or circular band of pale yellow tissue 1 to $3 \mathrm{~cm}$ wide. Disease severity (percent of colony affected by disease) increased over time, due to the appearance of multiple lesions on individual colonies which coalesced with other lesions as they progressively radiated outward. YBD lesions were observed simultaneously on up to 6 ramets of a single genet of Montastraea annularis.

Signs of recent partial mortality included diseases, bleaching, predation and competition, although these conditions were rare or absent in 1995 and 1996, and increased substantially in 1999 and 2000. In 1999, 22\% of coral species (pooled species excluding Montastraea annularis complex) exhibited signs of recent mortality that affected $4.6 \%$ of their planar surface area, while $39.5 \%$ of $M$. annularis colonies exhibited recent mortality affecting a mean of $8.6 \%$ of their surface. White plague (WP) was the most widespread disease observed among all species ( $\mathrm{n}=24$ cases; $1.1 \%)$, followed by black band disease (BBD; $0.1 \%)$. $M$. annularis (species complex) was also affected by BBD and WP, as well as dark spots disease, predation by Sparisoma viride (focused biting and spot biting) and Coralliophila abbreviata, and overgrowth by tunicates (Trididemnum spp.), sponges (Cliona delitrix and Anthosigmella varians), and cnidarians (Erythropodium caribbaeorum and Millepora spp.).

YBD was not observed in permanent sites or in other locations around Mona in 1995. Colonies with YBD ( $\mathrm{n}=$ 4) were first recorded in 1996 within 2 sites at Carmelitas South. An outbreak of YBD was documented in 1999 in shallow sites off the west coast. YBD was least common at the deepest site located furthest to the east (Carbinero, $\mathrm{n}=2$ ) in 1999, while the highest prevalence was recorded within Carmelitas South, where a maximum of $52 \%$ of the colonies of Montastraea annularis (species complex) were affected. Additional corals were identified with YBD each year in all sites, with a progressive increase in the number of infections in deeper sites to the east. Additional new infections were identified during 2001 and 2003, although the incidence is lower than observed in 1999 and 2000 (Fig. 3).
On large colonies of $M$. faveolata individual yellow band lesions were up to $2.5 \mathrm{~m}$ in length, with a maximum of 18 multifocal lesions occurring at one time. A prominent band of white recently exposed skeleton was never observed adjacent to affected tissue; tissue died in an irregular pattern, with small patches of white exposed skeleton (1 to $5 \mathrm{~cm}$ in length and up to $4 \mathrm{~cm}$ wide) often observed within the band (Fig. 4).

The prevalence of YBD differed among species, with Montastraea annularis colonies being infected most frequently, and fewest infections observed in $M$. franksi. It is unclear whether these differences are due to varying susceptibilities among the 3 species, or to other factors such as depth or nutrients, as $M$. annularis was most common on shallowest sites (Carmelitas) where YBD prevalence was highest overall. Carmelitas is also the most protected site and closest to the most devel-

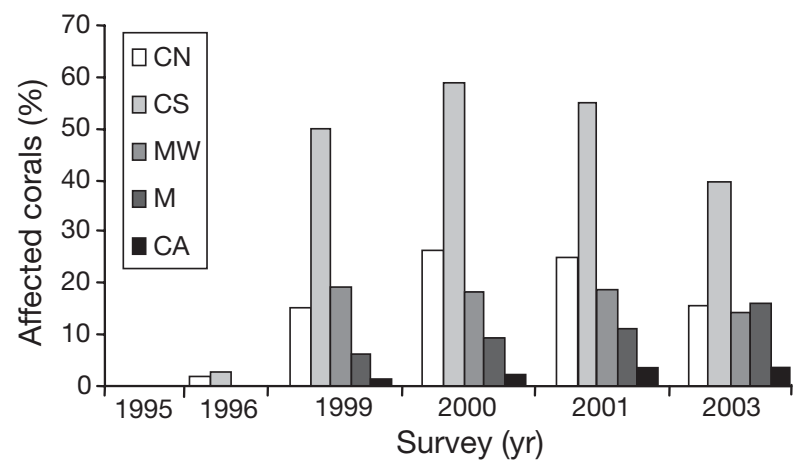

Fig. 3. Montastraea annularis (species complex). Prevalence of yellow band disease (YBD) on 5 reefs off Mona Island, Puerto Rico, between 1995 and 2003. The percent of affected colonies refers only to $M$. annularis species complex. For abbreviations of sites see Fig. 1 

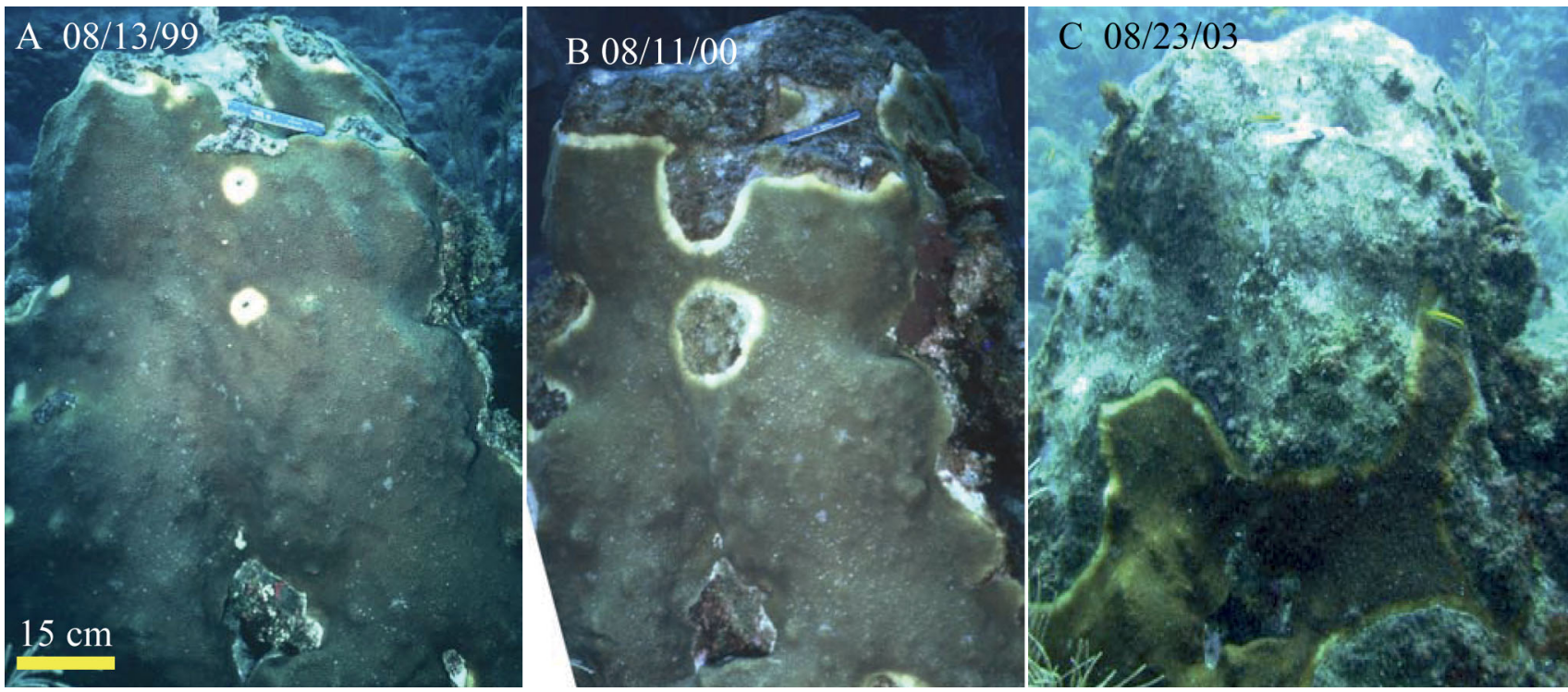

Fig. 4. Montastraea faveolata. Progression of YBD on a colony over $4 \mathrm{yr}$. This coral is over $1 \mathrm{~m}$ in height and diameter. Scale bar $=$ $15 \mathrm{~cm}$. (A) Colony when first identified with YBD in August 1999. YBD in 2 spots in the center, 2 on the left and a band at the top. (B) Same coral in August 2000. The circular patch of affected tissue has coalesced with the band and continues to radiate down.

(C) Condition of the colony in August 2003. YBD has advanced over $40 \mathrm{~cm}$, with tissue losses in excess of $60 \%$, and is still active

oped portion of the island as well as being adjacent to bat roosting areas that were once harvested for guano.

There were significant differences in the sizes of infected and uninfected Montastraea annularis (species complex) colonies ( $t$-test, $\mathrm{p}<0.01)$. Colonies with YBD were larger (average diameter $=98 \mathrm{~cm}$ ) than uninfected corals, with $>25 \%$ of the small corals (less than $50 \mathrm{~cm}$ ) becoming infected. Colonies without YBD had a mean diameter of $75 \mathrm{~cm}$, of which almost half were less than $50 \mathrm{~cm}$ diameter (Fig. 5). Colonies with YBD also had a higher percentage of partial mortality $($ mean $=32 \%)$ than uninfected colonies (mean = $17.6 \%$ ) when first examined in 1999 (Fig. 6).

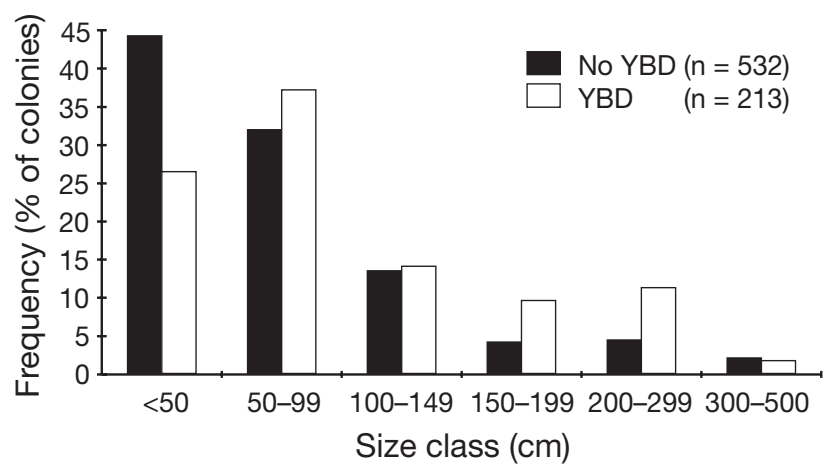

Fig. 5. Montastraea annularis (species complex). Maximum diameter of colonies without (black bars) YBD and with (white bars) YBD. M. annularis colonies were larger than all other species $($ mean $=98 \mathrm{~cm})$, and colonies with YBD were larger than uninfected corals $($ mean $=75 \mathrm{~cm})$ of the same species
The linear progression of YBD averaged between 5 and $10 \mathrm{~mm} \mathrm{mo}^{-1}$, with minor differences observed between reefs, years, and among individual corals. The fastest rate of advance of YBD for all tagged colonies (pooled for all reefs) was observed between 1999 and $2001\left(8-10 \mathrm{~mm} \mathrm{mo}^{-1}\right)$, with a decline to $6-7 \mathrm{~mm} \mathrm{mo}^{-1}$ from 2001 to 2003 ( $t$-test, $\mathrm{p}<0.001$ ). Minor (non-significant) variations were also observed between summer (May to August) and the rest of the year (August to May) ( $t$-test, $\mathrm{p}=0.06$ ). Significant differences in progression were measured on the 4 reefs (ANOVA, p = 0.01), with a faster rate observed on Carmelitas South and Mujeres West (Fig. 7).

Tagged colonies with YBD lost an average of $32 \%$ of their live tissue from YBD over $4 \mathrm{yr}$. The percent of partial mortality appeared to increase with colony size, as estimated by regression $\left(r^{2}=0.38, p<0.01\right)$ (Fig. 8). In August 2003, $85 \%$ of the tagged colonies still had active signs of YBD. For the remainder of the colonies identified with YBD in 1999 or 2000, 7 \% experienced partial mortality and are now in remission, and $8 \%$ died. Most corals that died were less than $50 \mathrm{~cm}$ diameter. Many of the larger corals with YBD are now missing 60 to $85 \%$ of their tissue, including several that have lost up to $2 \mathrm{~m}^{2}$ of tissue.

\section{DISCUSSION}

Outbreaks of coral diseases are occurring with increasing frequency throughout the western Atlantic 


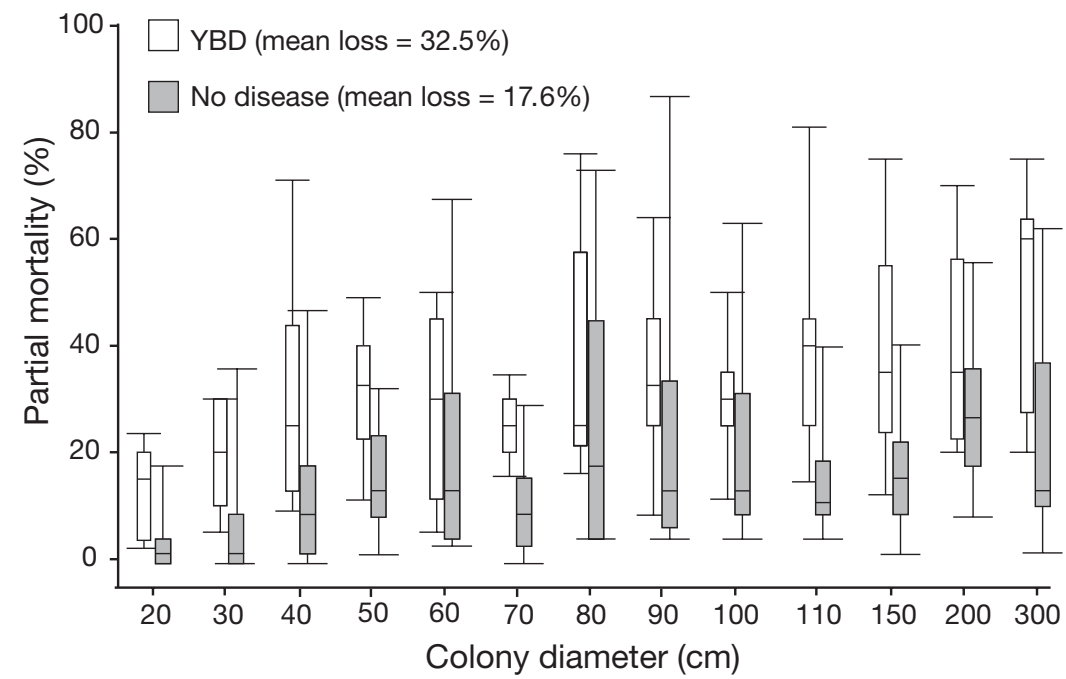

Fig. 6. Montastraea annularis (species complex). Box plot showing the percentage of partial mortality for different size classes of $M$. annularis (species complex) in 1999. Gray bars are uninfected colonies and white bars are colonies with YBD. The bar illustrates the tissue mortality for colonies within the 25 and 75 percentile; the line within the bar is the median amount of tissue lost. Error bars reflect the range of tissue loss for $95 \%$ of the colonies

and these are playing an increasingly important role in regulating coral population size, diversity and demographic characteristics (Green \& Bruckner 2000, Aronson \& Precht 2001). However, the rate and extent of tissue loss from coral diseases is highly variable, depending on its virulence, the susceptibility and resilience of the host, synergistic effects of environmental parameters, and the duration of infections (Bruckner 2002). In some cases, affected corals are killed over a period of days to months (Richardson et al. 1998). For instance, WP has emerged as the most virulent of the diseases reported to affect Montastraea spp., with rates of mortality of $2 \mathrm{~cm}$ or more $\mathrm{d}^{-1}$ (Richardson \& Aronson 2002). Other diseases, such as BBD, advance much more slowly and cause partial
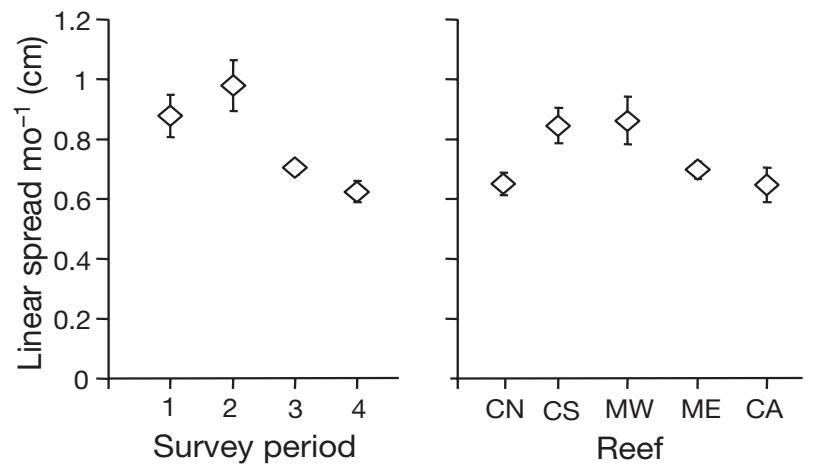

Fig. 7. Linear rate of progression $\left(\mathrm{cm} \mathrm{mo}^{-1}\right)$ of YBD during different years (left) and on different reefs (right). Values are the mean rate of spread $\left(\mathrm{cm} \mathrm{mo}^{-1}\right): 1=$ May-Aug 2000; $2=$ Aug 2000-May 2001; 3 = Aug 2001-May 2003; 4 = May-Aug 2003. Bars $=$ SE. For abbreviations of sites see Fig. 1 mortality more frequently than total mortality, giving colonies the potential for recovery through continued growth once the disease disappears (Bruckner 1999).

In recent years Montastraea annularis complex has become the most susceptible coral species to diseases, with colonies affected by as many as 8 different diseases (Weil 2004), as well as numerous other biotic stressors. YBD was first reported from the Florida Keys in 1994, and is now commonly observed throughout much of the Western Atlantic (Weil 2004). An outbreak of YBD was first observed on these reefs in 1999, and the disease rapidly spread from shallow sites to deeper locations. In other locations throughout the Caribbean, including Panama, the Netherland Antilles, Colombia, Mexico, and Venezuela, researchers reported a similar sudden emergence of YBD in the mid to late 1990s and a dramatic increase in the number of infections, with prevalence rates that are comparable to the rate observed in the present study (e.g. 18 to $91 \%$; Santavy et al. 1999, Cervino et al. 2001, Bruckner \& Bruckner 2003, Gil-Agudelo et al. 2004, JordánDahlgren \& Rodríguez-Martínez 2004). The prevalence of YBD is among the highest reported for any coral disease, with the exception of one study in Florida which examined aspergillosis (Kim \& Harvell 2004).

Under natural conditions YBD has been shown to cause relatively slow rates of tissue loss, ranging from 0.5 to $1 \mathrm{~cm} \mathrm{mo}^{-1}$, as observed in Bonaire, Curaçao, Venezuela, and in the present study (Bruckner \& Bruckner 2003, Cervino et al. 2001, Cróquer et al. 2004). In contrast, experimentally increased nutrient

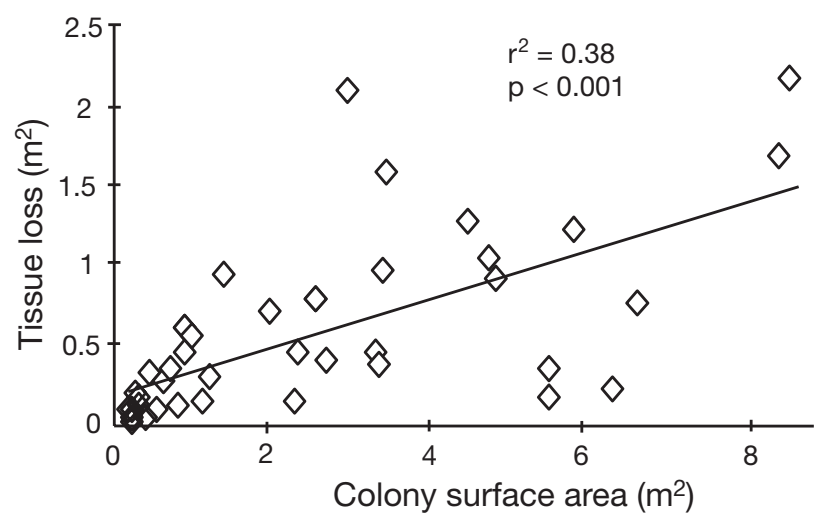

Fig. 8. Extent of tissue loss (planar surface area) as of August 2003 in colonies with YBD which had been tagged in 1999 or 2000 
levels nearly doubled the rate of tissue loss from YBD in Mexico (Bruno et al. 2003). While this suggests that moderate nutrient enrichment can increase the severity of diseases, YBD currently appears to be most abundant in remote locations with a low degree of nutrient pollution, including offshore locations with high water clarity and areas removed from human population centers (Bruckner \& Bruckner 2003, Weil 2004). Sites examined around Mona Island are subjected to very low levels of anthropogenic nutrients due to their remote nature, minimal development and the absence of permanent residents. While increased rates of tissue loss from YBD under conditions of nutrification are problematic, it is possible to mitigate nutrient inputs through implementation of specific coastal zone management measures. The high prevalence of YBD in offshore locations may be more of a concern, however, because it suggests that other unidentified factors may regulate the occurrence of YBD outbreaks and the persistence of infections. Without understanding these factors, it is not currently possible to mitigate YBD.

The progression of YBD may go unnoticed by annual monitoring surveys or be mistaken for bleaching, since the occurrence of prominent areas of white, exposed skeleton is rare, suggesting that it is of minor importance in structuring reef communities. In contrast, repeat examination of sites and infected corals suggests that YBD is significant over the long term. On reefs surrounding Mona Island, individual colonies have exhibited signs of YBD and associated progressive mortality for more than $5 \mathrm{yr}$, with only a limited number of cases where YBD has gone into remission, but no recovery. Colonies with YBD were missing about $30 \%$ of their tissue when first identified as having YBD, as compared to $16 \%$ partial mortality in uninfected corals. After $4 \mathrm{yr}$, colonies with YBD were missing over $60 \%$ of their tissue.

While corals which experience partial mortality have the potential for recovery once the disease is eliminated, a reduction in size may affect growth, reproduction, resistance to injury and other diseases, and competitive abilities of the surviving polyps (Edmunds 2000). In the present study, surviving portions of colonies have failed to exhibit regrowth of tissue, and surfaces denuded by YBD have been colonized by macroalgae, cyanobacteria, clionid sponges and other competitors. Several of the colonies with YBD were later infected by BBD and WP, which cause mortality at a much faster rate, exacerbating losses associated with YBD. Furthermore, preliminary observations on patterns of recruitment have shown a complete absence of Montastraea spp. recruits on reef substrates and on exposed skeletal surfaces, and only limited recruitment of brooding species such as Agaricia agaricites and Porites astreoides.
With the Caribbean-wide decline of Acropora cervicornis and A. palmata, Montastraea annularis (species complex) are now the most abundant and important reef-building corals on Caribbean reefs (Jackson 1992, Aronson \& Precht 2001). Outbreaks of BBD, WP and YBD have become more frequent in recent years, and are contributing to the decline of these species throughout the region (Bruckner 1999, Richardson \& Aronson 2002, Bruckner \& Bruckner 2003,). YBD emerged as a significant threat to fore reef communities ( 5 to $25 \mathrm{~m}$ ) of Mona Island in 1999. Because of the high prevalence of YBD, long duration of individual infections, and the appearance of multiple YBD infections on single corals, the overall amount of tissue loss from YBD has been substantial. This disease may be even more destructive over the long term, because the dominant corals found on these reefs are susceptible and YBD specifically affects the largest and oldest colonies, which are presumably the most important in terms of their contribution to the persistence of the species through new recruits (Szmant 1991).

Overall, the population size and structure of Montastraea annularis (complex) remained largely unchanged over the course of the outbreak, largely due to the large size of affected corals and the slow rates of mortality from YBD. However, the long duration of infections, and continued progressive mortality from YBD suggests that numerous larger colonies will die in the next few years. While the structure created by these corals will remain for many years, the extent of partial tissue loss is likely to affect reproductive potentials, and the colonization of exposed skeletal surfaces by pest species and the potential regrowth of corals through resheeting. High rates of mortality due to the continued spread of YBD and other emerging coral diseases may lead to reduced rates of reef accretion, and possibly a restructuring of the reef community from one dominated by long-lived, slowgrowing massive reef-builders to one dominated by smaller, shorter-lived corals such as Agaricia and Porites.

Acknowledgements. Financial support was provided by a grant from Earthwatch Institute (1999 to 2001), National Oceanic and Atmospheric Administration (NOAA) Fisheries Office of Habitat Conservation, NOAA Coral Reef Conservation Program (2003) and the University of Puerto Rico (1995 to 1996). Boat transportation and dive support was partially funded through support from Mona Aquatics, the Viking Diver and P. Sollins. We are grateful for the assistance provided by 6 groups of Earthwatch volunteers, and students and colleagues from the University of Puerto Rico. Technical reviews were provided by L. Fairey, T. Hourigan and M. Sherer. The opinions and views expressed in this document are those of the authors and do not necessarily reflect those of the National Marine Fisheries Service, NOAA, or the U.S. Government. 


\section{LITERATURE CITED}

Aronson RB, Precht WF (2001) White-band disease and the changing face of Caribbean coral reefs. Hydrobiologia 460:25-38

Bruckner AW (1999) Black band disease (BBD) of scleractinian corals: occurrence, impacts and mitigation. PhD dissertation, University of Puerto Rico, Mayaguez

Bruckner AW (2002) Priorities for effective management of coral diseases. NOAA Tech Memo NMFS-OPR-22, August 2002

Bruckner AW, Bruckner RJ (1997a) Outbreak of coral disease in Puerto Rico. Coral Reefs 16:260

Bruckner AW, Bruckner RJ (1997b) The persistence of blackband disease in Jamaica: impact on community structure. Proc 8th Int Coral Reef Symp 1:601-606

Bruckner AW, Bruckner RJ (2003) Condition of coral reefs off less developed coastlines of Curaçao (stony corals and algae). Atoll Res Bull 496:370-393

Bruno JF, Petes LE, Harvel CD, Hettinger A (2003) Nutrient enrichment can increase the severity of coral diseases. Ecol Lett 6:1056-1061

Cervino J, Goreau TJ, Nagelkerken I, Smith GW, Hayes R (2001) Yellow band and dark spot syndromes in Caribbean corals: distribution rate of spread cytology and effects on abundance and division rate of zooxanthellae. Hydrobiologia 460:53-63

Cróquer AA, Weil E, Bone D (2004) Temporal variation in tissue mortality of Montastraea faveolata with yellow blotch syndrome at Morrocoy National, Venezuela. Proc 10th Int Coral Reef Symp Abstracts Oral 1-4-B:169

Edmunds PJ (2000) Recruitment of scleractinians onto the skeletons of corals killed by black band disease. Coral Reefs 19:69-74

Gil-Agudelo Dl, Smith GW, Garzón-Ferreira J, Weil E, Peterson D (2004) Dark spots disease and yellow band disease, two poorly known coral diseases with high incidence in Caribbean reefs. In: Rosenberg E, Loya Y (eds) Coral health and disease. Springer, Berlin, p 337-350

Goenaga C, Boulon RH (1992) The state of Puerto Rican and US Virgin Island corals: an aid to managers. Caribbean Fish Management Council, Hato Rey

Green EP, Bruckner AW (2000) The significance of coral disease epizootiology for coral reef conservation. Biol Conserv 96:347-361

Submitted: August 6, 2005; Accepted: November 7, 2005
Harvell CD, Kim K, Burkholder JM, Colwell RR and 9 others (1999) Emerging marine diseases_climate links and anthropogenic factors. Science 285:1505-1510

Hayes RL, Goreau N I (1998) The significance of emerging diseases in the tropical coral reef ecosystem. Rev Biol Trop 46:173-185

Jackson JBC (1992) Pleistocene perspectives on coral reef community structure. Am Zool 32:719-731

Jordán-Dahlgren E, Rodríguez-Martínez RE (2004) Coral diseases in Gulf of Mexico Reefs. In: Rosenberg E, Loya Y (eds) Coral health and disease. Springer, Berlin, p 105-118

Kim K, Harvell CD (2004) The rise and fall of a six year coralfungal epizootic. Am Nat 164:S52-S63

Richardson L, Aronson RB (2002) Infectious diseases of reef corals. Proc 9th Int Coral Reef Symp 2:1225-1230

Richardson L, Goldberg WM, Kuta KG and 6 others (1998) Florida's mystery coral killer explained. Nature 392: 557-558

Santavy DL, Peters EC (1997) Microbial pests: coral disease in the Western Atlantic. Proc 8th Int Coral Reef Symp 1:607-612

Santavy DL, Peters EC, Quirolo C, Porter JW, Bianchi CN (1999) Yellow-blotch disease outbreak on reefs of the San Blas Islands, Panama. Coral Reefs 18:97

Sutherland KP, Porter JW, Torres C (2004) Disease and immunity in Caribbean and Indo-Pacific zooxanthellate corals. Mar Ecol Prog Ser 266:273-302

Szmant AM (1991) Sexual reproduction by the Caribbean reef corals Montastrea annularis and M. cavernosa. Mar Ecol Prog Ser 74:13-25

Weil E (2004) Coral reef diseases in the wider Caribbean. In: Rosenberg E, Loya Y (eds) Coral health and disease. Springer, Berlin, p 35-68

Weil E, Urreiztieta I, Garzón-Ferreira J (2002) Geographic variability in the incidence of coral and octocoral diseases in the wider Caribbean. Proc 9th Int Coral Reef Symp 2:1231-1237

Williams EH Jr, Bunkley-Williams L (1990) The world-wide coral reef bleaching cycle and related sources of coral mortality. Atoll Res Bull 335:1-71

Woodley CM, Bruckner AW, Galloway SB, McLaughlin SM, Downs CA, Fauth JE, Shotts EB, Lidie KL (eds) (2003) Coral disease and health: a national research plan. National Oceanic and Atmospheric Administration, Silver Spring, MD

Proofs received from author(s): February 3, 2006 